\title{
SISTEM PENDUKUNG KEPUTUSAN MENENTUKAN KUALITAS BIJI KAKAO DENGAN MENGGUNAKAN METODE MULTIDIENSIONAL SCALING (STUDI KASUS: PT. TANAH MAS CELEBES INDAH KABUPATEN POSO)
}

\author{
Triyanti Kusuma Bangsa'), Mohammad Sofyan S. Thayf ${ }^{2)}$, Marlina $^{3)}$ \\ ${ }^{1}$ Sistem Informasi, STMIK KHARISMA \\ email: triyantikusuma_15@kharisma.ac.id \\ ${ }^{2}$ Sistem Informasi, STMIK KHARISMA \\ email: sofyanthayf@gmail.com \\ ${ }^{3}$ Sistem Informasi, STMIK KHARISMA \\ email: Marlina@kharisma.ac.id
}

\begin{abstract}
The problem at PT. TMCI is that the lab part is still confused in determining the quality of some cocoa beans, because there is no average calculation. So that the quality of cocoa depends only on the specified parameters, and the moisture content, the count of cocoa beans as the first determinant of quality. The purpose of this study is to make a decision model in a decision making with the Multidimensional Scaling method, and a decision support system as a decision maker in determining the quality of cocoa beans, and implementing a decision support system and calculation of MDS metrics with several parameters, namely based on moisture content, moudly, broken beans, weight of waste, number of cocoa beans and flat cocoa beans. Then apply the MDS method in an Android-based application system, so that from the calculation results can determine which quality is good and which will be mixed again. Data collection is done by observing conditions directly, and conducting interviews. From the results of testing implementation, interviews and testing applications, that the application works properly when used. In terms of appearance and function the application can help the lab and the owner at the time of supplying supplier data. So it was concluded that this application could be well received and answer the problems of the lab and the owner.
\end{abstract}

\section{Keywords: Multidimensional Scaling, Quality Of cacao Beans, Decision Support System}

\section{PENDAhUluAN}

Sehubungan dengan perkembangan zaman kualitas biji kakao mulai menurun, dan daya saing kakao semakin tinggi, begitu pula untuk pengiriman biji kakao ke beberapa perusahaan besar terkadang para pembeli menginginkan kualitas biji kakao yang baik dengan memberikan permintaan sesuai standar mereka kepada para perusahaan pengolah biji kakao mentah. Maka dari itu perlunya pensampelan yang baik dalam menentukan kualitas sesuai dengan permintaan pembeli biji kakao tersebut. Sulawesi Tengah adalah salah satu dari pulau-pulau di Indonesia yang daerah-daerahnya banyak menanam bibit kakao, salah satu daerah ataupun kota di Sulawesi
Tengah yang terdapat beberapa warganya berprofesi sebagai petani kakao yaitu di Parigi Moutong, Poso, Donggala, Sigi, Tolitoli, Morowali, Morut dan Banggai. PT. Tanah Mas Celebes Indah (TMCI) yang berada di kota Poso adalah anak cabang dari PT. TMCI pusat yang berada di kota Palu, pada PT. TMCI ini dimana terjadi pengolahan kakao dan pensampelan pada tempat tersebut. Pada PT. TMCI tidak memiliki kebun coklat sendiri, melainkan mereka mendapatkan biji kakao dengan membeli dari supplier, atau petani kakao yang ada di sekitar kawasan tersebut. Selain itu PT. TMCI ini tidak terlalu mementingkan jenis biji kakao, karena menurut PT. TMCI semua biji sama saja, asalkan biji-biji tersebut kering, dan KA (kadar air) sesuai dengan standar. Rata-rata biji yang mereka beli dari 
para supplier adalah biji dari bibit lokal. Masalah atau kendala yang PT. TMCI alami yaitu, kesulitan dalam menentukan kualitas biji kakao dari supplier karena kualitas yang ada tergantung pada berat biji, patahan biji kakao, sampah atau kotoran, dan kadar air pada biji tersebut yang nantinya sebagai penentu standar baik tidaknya biji kakao tersebut, dan jikalau biji kakao tidak sesuai dengan permintaan kualitas yang ditentukan oleh perusahaan yang menjadi langganan PT.TMCI cabang Poso maka kakao tersebut harus di mix kembali dengan kakao yang memiliki KA yang baik maka dari itu, peneliti akan mengadakan studi kasus penelitian di kota Poso Sulawesi Tengah. Sebagai objek, atau tempat yang akan peneliti gunakan sebagai tempat penelitian, guna membantu menentukan kualitas biji kakao yang baik, dan yang akan layak dikirim ke perusahaan lain. Peneliti akan meneliti dengan beberapa parameter yang sudah ada, untuk menentukan apakah biji kakao tersebut layak atau tidak layak untuk di kirimkan ke langganan PT. TMCI yaitu menentukan berat biji kakao, broken/Patahan pada biji kakao, kadar air yang terkandung di dalam kakao, sampah pada biji kakao, menentukan biji kakao yang kempes atau tidak ada biji di dalamnya, biji Bagus. Dari parameter yang telah peneliti sebutkan, peneliti akan menggunakan Sistem Penunjang Keputusan (SPK) dalam menentukan keputusan dalam memilih biji kakao yang baik. SPK adalah sebuah sistem yang mampu memberikan kemampuan pemecahan masalah maupun kemampuan pengkomunikasian untuk masalah dengan kondisi semi terstruktur dan tak terstruktur. Sistem ini digunakan untuk membantu pengambilan keputusan dalam situasi semi terstruktur dan situasi yang tidak terstruktur, dimana tak seorangpun tahu secara pasti bagaimana keputusan seharusnya dibuat Turban (2005). Maka dari itu peneliti juga menggunakan metode Multidimensional Scaling (MDS) sebagai pembobotan dalam menentukan kualitas biji kakao. MDS merupakan sekelompok prosedur, untuk menggambarkan persepsi, dan preferensi responden secara visual, sebagai hubungan geometris antara beberapa hal dalam suatu ruang multidimensi. Dalam riset pemasaran, analisis MDS digunakan untuk mengetahui persepsi konsumen terhadap beberapa produk, dan hubungan antara atribut-atribut produk. Tujuan dari MDS adalah untuk memberikan gambaran visual, dari pola kedekatan yang berupa kesamaan, atau jarak diantara sekumpulan objek-objek. Maka dari itu, penulis menggunakan metode MDS sebagai penentu keputusan, untuk membobot biji kakao yang akan dikirim nantinya ke langganan PT. TMCI.

\section{LANDASANTEORI}

\subsection{Sistem Penunjang Keputusan (SPK)}

SPK biasanya di bangun untuk mendukung solusi untuk suatu masalah atau untuk suatu peluang. SPK menggunakan CBIS (Computer Based InFormation Systems) yang fleksibel, interaktif, dan dapat beradaptasi, yang di kembangkan dapat mendukung solusi atas masalah manajemen spesifik yang tidak terstruktur [1]. komponen-komponen pada SPK, suatu SPK dapat di aplikasi menjadi tersusun pada subsistem:

1.Data Management Subsystem, pada data manajemen subsistem terdapat sebuah data base, yang berisi data yang relevan untuk sebuah situasi dan dikelola oleh software bernama Data base management system (DBMS).

2.Model Management Subsystem, adalah sebuah paket perangkat lunak termasuk statistik keuangan, manajemen sains, atau model kuantitatif yang lain yang menyediakan kemampuan analitis sistem dan sesuai software manajemen. Bahasa pemodelan untuk membangun model kebiasaan yang juga termasuk didalamnya. Perangkat lunak ini sering di ucapkan seuai model base management system (MBMS)

3.Knowledge-based Management subsystems, subsistem ini dapat mendukung subsistem lainnya atau bertindak sebagai suatu komponen independen. Menyediakan kecerdasan untuk intelijen pembuat keputusan itu sendiri. Dapat saling berhubungan dengan organisasiorganisasi tempat penyimpanan pengetahuan, yang disebut basis pengetahuan organisasi.

4.User Interface Subsystems, pengguna berkomunikasi dengan perintah pada sub sistem [2].

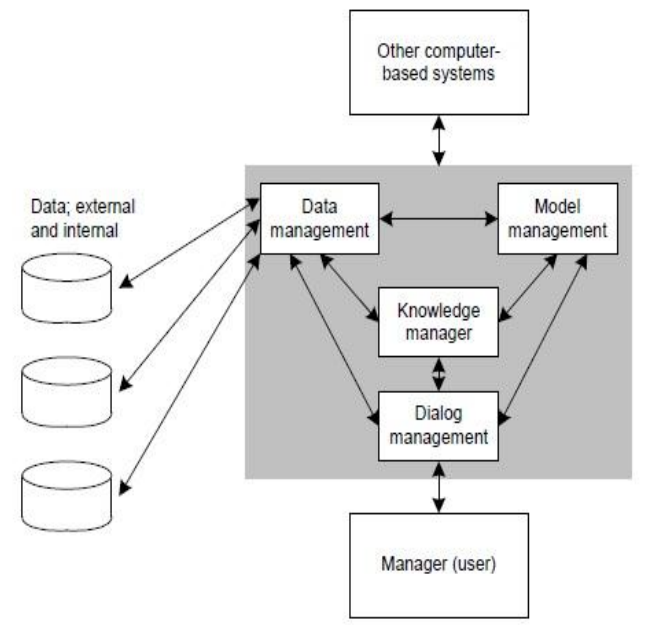

Gambarl Komponen SPK (Turban \& Aronson, 2005) 


\subsection{MDS (Multidimensional Scaling)}

Multidimensional Scaling (MDS) adalah salah satu metode analisis yang bertujuan untuk mentransformasikan bagaimana penilaian konsumen terhadap kemiripan, atau perferensi terhadap sesuatu, contohnya penilaian kemiripan suatu produk. Multidimensional Scaling (MDS) dapat menunjukkan dimensi penilaian dari responden secara langsung ke dalam pola visualisasi kedekatan mengenai suatu produk. Karena keunggulan inilah MDS merupakan suatu alat yang paling umum digunakan dalam pemetaan perceptual (perceptual maping). Konsep multidimensional Konsep ini bertujuan untuk mengubah penilaian konsumen mengenai persamaan atau preferensi mereka (misalnya, preferensi atau pilihan mereka akan toko, merek, produk tertentu) ke dalam representasi grafis dengan tata letak dan jarak ke dalam suatu ruang atau bidang multidimensi. Jenis-jenis MDS untuk melakukan analisis data MDS digunakan nilai-nilai yang menggambarkan tingkat keminipan atau tingkat ketakmiripan antar objek yang disebut proximity yang terbagi atas similarity (kemiripan) dan dissimilarity (ketakmiripan)[3].

\section{MDSMetrik}

Jarak yang digunakan dalam penskalaan berdimensi ganda metrik adalah data rasio. $P$ penskalaan berdimensi ganda metrik digunakan untuk menemukan himpunan titik dalam ruang dimensi $n$ dimana masing-masing titik mewakili satu objek. Sedangkan menurut data jarak yang digunakan dalam multidimensional scaling metrik adalah data rasio atau interval [3]. Sedangkan MDS metrik (classical scaling) digunakan untuk menemukan himpunan titik dalam ruang dimensi n dimana masingmasing titik mewakili satu objek. Dalam classical scaling, dissimilarities $\left(\delta_{i j}\right)$ diperlakukan sama dengan jarak $\left(d_{\mathrm{ij}}\right)$, yaitu $\delta_{\mathrm{ij}}=d_{\mathrm{ij}}$. Tujuan dari multidimensional scaling adalah untuk mencari koordinat titik-titik dalam ruang euclid dari matriks jarak yang tersedia. Misalkan koordinat $n$ titik dalam ruang euclid dimensi $p$ adalah $\boldsymbol{x}_{\boldsymbol{i}}$ (i $=1,2, \ldots, \mathrm{n})$ dengan $\boldsymbol{x}_{i=}\left(\boldsymbol{x}_{i 1}, \boldsymbol{x}_{i 2}, \ldots, \boldsymbol{x}_{\boldsymbol{j} k}\right)$ dan $\boldsymbol{x}_{\boldsymbol{j}}=$ $\left(\boldsymbol{x}_{j 1}, \boldsymbol{x}_{j 2}, \ldots, \boldsymbol{x}_{\boldsymbol{j} k}\right)$. Jarak euclid antara titik ke- $i$ dan ke- $j$ adalah:

$$
d^{2} i j=\sum_{k}^{p}={ }_{1}\left(x_{i k}-x_{j k}\right)^{2}
$$

Langkah berikutnya adalah menentukan matriks hasil kali dalam $\mathbf{B}$, dengan cara mendekomposisikan matriks D melalui proses double centering. Matriks B memiliki elemen-elemen:

$$
b_{i j}=-\frac{1}{2}\left(d^{2} i j-d^{2} i-d^{2} j-d^{2}\right)
$$

Bila ditulis dalam bentuk matriks menjadi:

$$
\mathrm{B}=-\frac{1}{2}\left(\mathrm{I}-\frac{1}{n} \mathrm{~V}\right) \mathrm{D}^{2}\left(\mathrm{I}-\frac{1}{n} \mathrm{~V}\right)
$$

Dimana:

I: matriks identitas dengan ukuran nxn

$V$ : matriks berukuran $\mathrm{n} \times \mathrm{n}$ dengan entri

$V_{i j}$ : untuk semuai, j

$D^{2}$ : matriks kuadrat jarak berukuran $\mathrm{n} \times \mathrm{n}$ dengan elemen $d_{i j 23}^{2}$

\subsection{Penelitian Terkait}

Peneliti menemukan sejumlah paper atau jurnal terkait, yaitu:

1.Penelitian yang dilakukan oleh (Hidayatul Ula, Dr. Manuharawati, M.Si., Volume 2 No.6 Tahun 2017). Tentang Analisis Posisi Produk Mie Instan Dengan Metode Multidimensional Scaling (MDS) Pada Mahasiswa Fmipa Universitas Negeri Surabaya. Dalam penelitian ini peneliti menggunakan metode MDS untuk mengetahui persepsi responde terhadap beberapa sampel mie instan. Dimana peneliti akan menggunakan parameter yang sudah peneliti tentukan dan melihat urutan mana diantara beberapa sampel mie instan yang disukai oleh para mahasiswa Fmipa dengan menghitung menggunakan MDS non-metrik. Dari hasil perhitungan akan dilihat yang mana mie yang paling banyak peminatnya [3].

2.Penelitian yang dilakukan oleh (Walundungo, Paendong, \& Manurung, 2014). Tentang Penggunaan Analisis Multidimensional Scaling Untuk Mengetahui Kemiripan Rumah Makan Di Manado Town Square Berdasarkan Kerakteristik Pelanggan [5].

\section{METODE PENELITIAN}

Teknik atau metode pengumpulan data yang digunakan peneliti dalam metode penelitian yaitu:

1.Wawancara, yaitu pengumpulan data yang dilakukan secara langsung dari sumbernya. Wawancara dilakukan terhadap pihak-pihak yang mengetahui dan berkaitan dengan penelitian ini, yaitu pimpinan atau pemilik penusahaan dan pegawai sampel biji kakao. Pada kegiatan wawancara digunakan untuk mengetahui informasi mengenai pensampelan biji kakao, mengetahui seputar tentang perusahaan, dan kriteria biji kakao yang baik pada perusahaan tersebut.

2.Studi Kepustakaan (Library Research), yaitu pengumpulan data yang diperoleh dari buku-buku ilmiah, laporan penelitian, tesis, artikel, website serta sumber-sumber tertulis baik dari elektronik atau dari media cetak sebagai sumber informasi terkait dengan penelitian.

3.Observasi, yaitu pengumpulan data diperoleh dengan langsung ke tempat objek yang dijadikan penelitian untuk melihat kondisi dan situasi di tempat tersebut. 
Observasi awal dilakukan pada tanggal 3 Juli 2018 sampai dengan 21 Juli 2018.

4 Analisis Data

Data dikumpulkan dari wawancara yang digunakan penulis sebagai dasar dalam pembuatan spesifikasi fungsi dari aplikasi yangdibuat.

\subsection{Rancangan Sistem Secara Umum}

Spesifikasi Kebutuhan Fungsi:

1.Menyediakan fasilitas form riset banu untuk input jumlah sampel sesuai jumlah supplier minimal 2 dan maksimal 20 atau $>=2$ dan $<=20$ sesuai jumlah supplier langganan PT. TMCI

2.Menyediakan fasilitas form riset baru input data-data biji kakao supplier sesuai parameter yang ditentukan, dan output dari data-data tersebut menampilkan perhitungan hasil riset setelah dirataratakan berupa grafik dan tabel data sebelum dirataratakan.

3.Menyediakan fasilitas pada form lanjutkan riset yaitu user dapat input data nomor sampel lanjutkan hasil riset, yang belum selesai untuk di lanjutkan kembali datanya.

4.Menyediakan fasilitas lihat hasil data riset yang selesai, lihat hasil riset yang nomornya tidak tersimpan di firebase, lihat hasil riset yang nomomya belum selesai di input.

5.Menyediakan fasilitas manajemen akun untuk membuat akun baru, dapat edit akun dan menghapus akun.

6. Menyediakan layanan atur standar untuk mengubah parameter atau kriteria penilaian standar yang ditentukan

\section{Uses Cases}

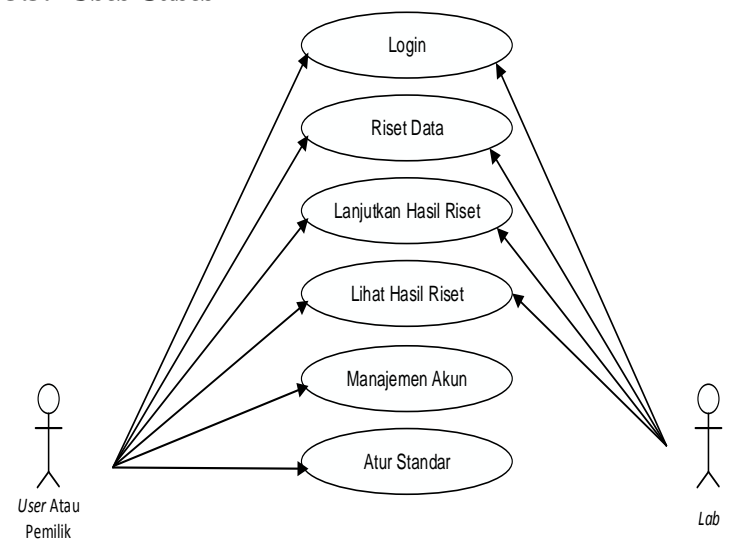

Gambar 3.3 Uses Cases

Pada gambar 3.3 dijelaskan bahwa aplikasi ini memiliki dua aktor yaitu aktor lab dan aktor pemilik. Semua kegiatan dapat dilakukan oleh aktor pemilik, akan tetapi kegiatan pada bagian aktor lab yaitu login, riset data, lanjutkan hasil, dan lihat hasil.

\subsection{Entity Relationship Diagram}

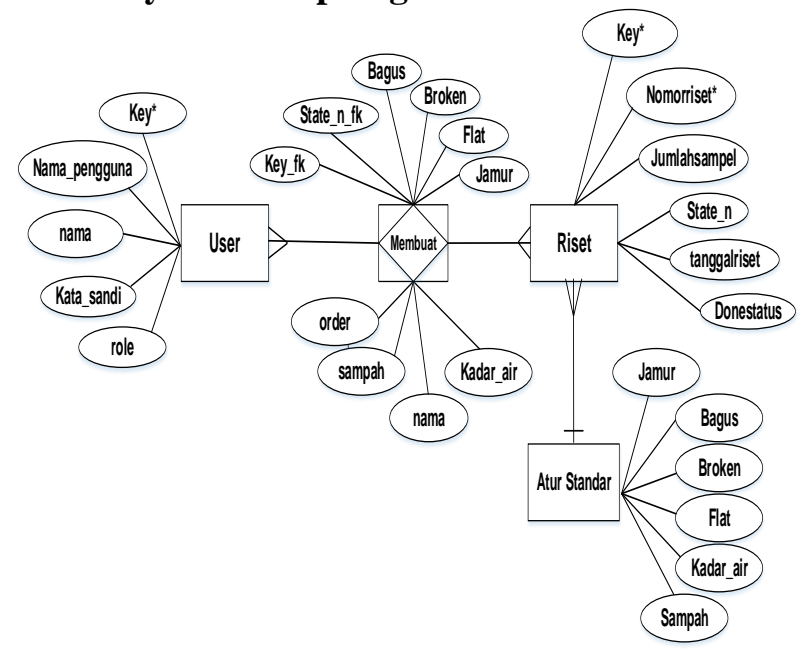

Gambar3.4Entity Relationship Diagram

Entity Relationship Diagram (ERD) dari aplikasi SPK menentukan kualitas biji kakao yang baik pada PT. TMCI ini memiliki 3 entitas, yaitu entitas user, entitas riset, dan entitas atur standar.

\section{HASIL DAN PEMBAHASAN}

Pengujian Implementasi:

a. Blackbox Testing

Metode pengujian aplikasi yang digunakan pada penelitian ini adalah black box testing dan pengujian metode MDS. Pengujian pada black box testing dilakukan dengan memasukkan semua data-data yang telah dikumpulkan yaitu, dari data 6 supplier yang di dapatkan dimana ada beberapa parameter yaitu kadar air, berat sampah, berat broken atau patahan biji, berat jamur, jumlah biji bagus, berat flat yang nantinya akan diinput oleh user atau pengguna untuk dikalkulasi menggunakan metode multidimensional scaling dan memberikan output berupa jarak euclidean dan SPK sebagai penentu yaitu menentukan supplier mana yang masuk ke batasan biji bagus dari nilai 0-350 kemudian biji yang akan dimix kembali dengan batasan jarak $>350$. Pengujian metode dilakukan dengan membandingkan hasil perhitungan secara manual dan hasil dari aplikasi. 


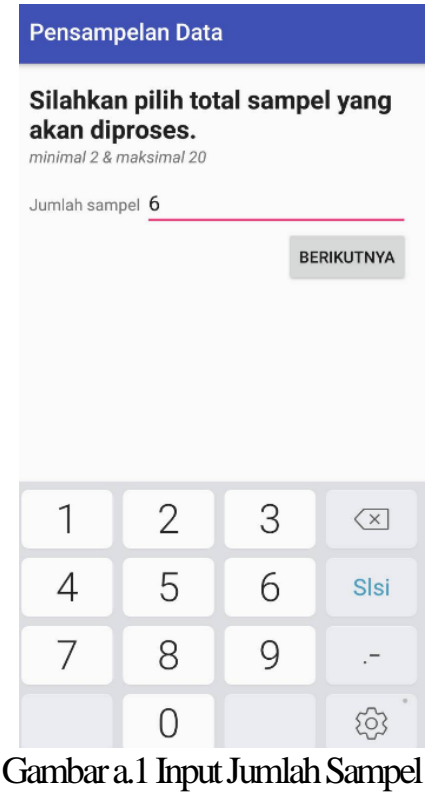

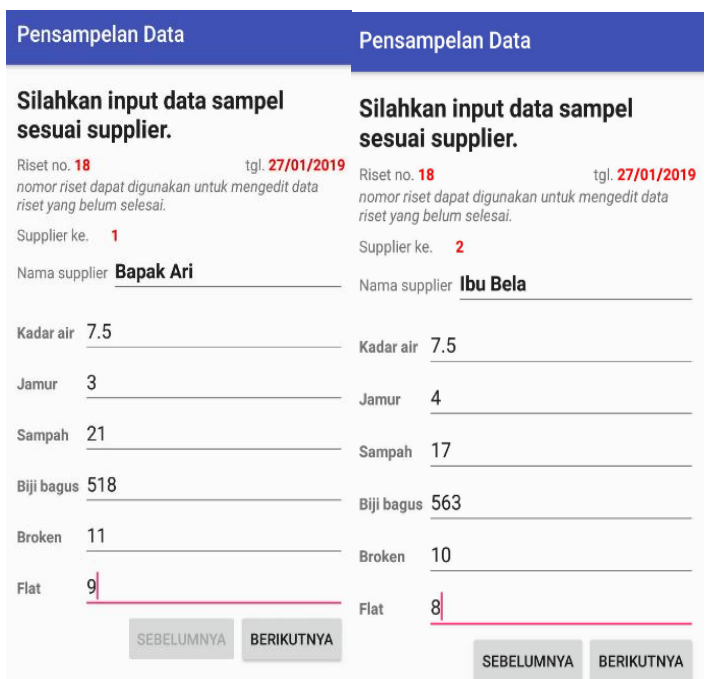

Gambar a.2 Input Data Sampel Sesuai Supplier Ke 1 Dan SupplierKe2

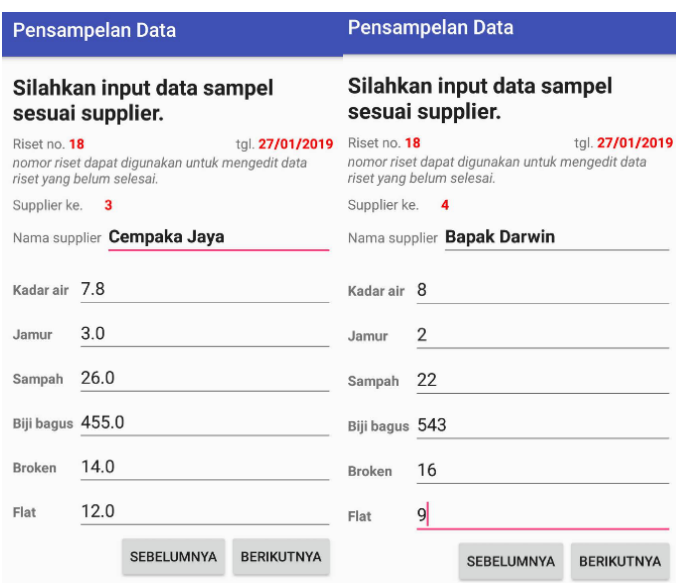

Gambar a.3 Input Data Sampel Sesuai Supplier Ke 3 Dan Supplier Ke4

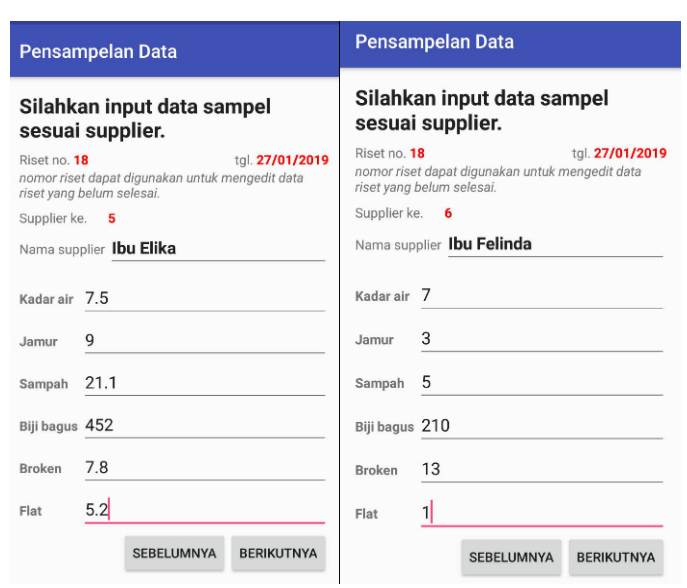

Gambar a.4 Input Data Sampel Sesuai Supplier Ke 5 Dan Supplier Ke 6

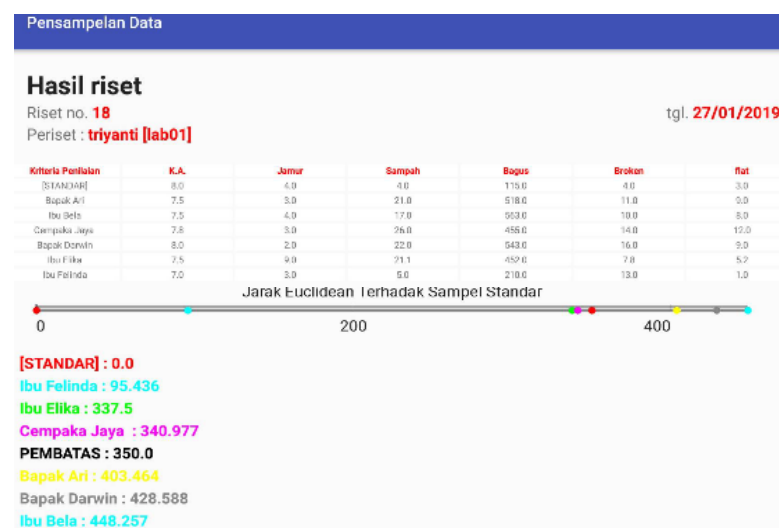

Gambar a.5 Output Tampilan Hasil Perhitungan Grafik Dan Tampilan Tabel

\section{b. Pegujian Implementasi}

Pada pengujian dalam implementasi penulis menggunakan teknik wawancara pada PT.TMCI di dapatkan hasil wawancara pada pemilik yang sudah mencoba menggunakan aplikasi yaitu, aplikasi dapat membantu dalam pensampelan data, dalam perhitungan, dan waktu lebih efisien, dan aplikasi dapat dibuka dimana saja saat pemilik sedang berpergian atau dalam urusan bisnis masih bisa memantau lewat aplikasi tersebut. Kemudian bagian pensampelan merasa aplikasi sangat membantu kinerja mereka, kendala yang di hadapi belum terbiasa menggunakan aplikasi tersebut, dan perhitungan bisa diterapkan tetapi semua kembali pada atasan jika mengizinkan aplikasi dapat di pakai dalam menentukan kualitas biji kakao. Beberapa jawaban dari tabel mengenai pengujian implementasi yang di dapatkan oleh penulis dari pemilik PT.TMCI cabang Poso menggunakan kuisioner pengujian implentasi sistem dan data yang di dapatkan sebagai berikut:

1. Pada pengujian sistem menu riset data didapatkan data yaitu tampilan menu data riset baik, fungsi yang diberikan baik, tampilan input data supplier baik, 
warna yang ditampilkan baik, grafik cukup baik, ukuran tulisan sangat baik.

2. Pada menu lanjutkan riset didapatkan data sebagai berikut tampilan pada menu lanjutkan riset baik, fungsi yang diberikan baik, warna pada tampilan baik, ukuran tulisan baik.

3. Pada menu lihat riset didapatkan data sebagai berikut tampilan pada menu lanjutkan riset baik, fungsi yang diberikan baik, warna pada tampilan baik, ukuran tulisan baik.

4. Pada menu manajemen akun hasil data yaitu tampilan menu manajemen sangat baik, fungsi yang diberikan baik, warna pada tampilan baik, ukuran tulisan baik, fungsi kolom akun bawah kolom button baik.

5. Pada menu atur standar tampilan menu atur standar sangat baik, fungsi yang diberikan sangat baik, warna pada tampilan sangat baik, wama pada tampilan sangat baik, dan ukuran pada tulisan baik.

\section{KESIMPULAN}

Berdasarkan hasil penelitian yang telah dilakukan oleh penulis terhadap masalah yang dihadapi maka penulis dapat menarik beberapa kesimpulan, antara lain adalah:

1.Metode MDS berhasil diimplementasikan dengan membangun, atau membuat suatau model keputusan dalam sebuah pengambilan keputusan dengan metode MDS, dan SPK sebagai penentu keputusan dalam menenukan kualitas biji kakao padaPT. TMCI

2.Penulis berhasil membangun SPK dengan metode MDS, beserta perhitungan metrik MDS dengan beberapa parameter yang ada yaitu berdasarkan kadar air, jamur, patahan biji, sampah, jumlah biji bagus dan flat. Kemudian menerapkan metode MDS dalam sistem aplikasi berbasis android sehingga di peroleh hasil perhitungan sesuai dengan perhitungan manual penulis.

3.Dari hasil pengujian implementasi aplikasi dan wawancara yang dilakukan pada PT. TMCI, kesimpulan dari hasil wawancara yaitu aplikasi berfungsi dengan baik saat digunakan, dari segi tampilan dan fungsi aplikasi dapat membantu bagian lab dan pemilik pada saat pensampelan data-data supplier. Dapat disimpulkan bahwa aplikasi ini dapat diterima dengan baik dan menjawab permasalahan bagian lab dan pemilik.

4.Kelebihan MDS pada studi kasus pada PT. TMCI yaitu multiparameter dan outputnya menghasilkan grafik yang dimana mempermudah pengguna dalam memahami jarak antara objek satu dengan objek lainnya.

\section{REFERENSI}

[1] Nofriansyah, D. (2014). Konsep Data Mining \& Sistem Pendukung Keputusan. Yogyakarta: Deepublish.

[2] Turban, E., \& Aronson, J. E. (2005). Decision Support System And Intelligent System Sixth Edition. New Jersey: Prentice Hall.

[3] Ula, H., \& Manuharawati. (2017). Analisis Posisi Produk Mie Instan Dengan Metode Multidimensional Scaling ( MDS ) Pada Mahasiswa FMIPA Universitas Negeri Surabaya. MATHunesa Jumal Ilmiah Matematika ISSN 2301-9115 Volume 2 No.6, 27-29.

[4] Imawati. (2017). Retrieved from PENERAPAN ANALISIS MULTIDIMENSIONAL SCALING PADA PEMETAAN KARAKTERISTIK KEMISKINAN DI PROVINSI SULAWESI SELATAN:repositori.uinlauddin.ac.id/6760/1//rma wati.pdf

[5] Walundungo, G., Paendong, M., \& Manunung, T. (2014). Penggunaan Analisis Multidimensional Scaling Untuk Mengetahui Kemiripan Rumah Makan Di Manado Town Square Berdasarkan Kerakteristik Pelanggan. de CARTESIAN,3(1),3035. 